\title{
Noise Induce Hearing Loss among Peshmerga in Erbil City Participated in Daesh War
}

\author{
Bayan Sabr Ibrahim (MSc) ${ }^{1}$
}

${ }^{1}$ College of Dentistry, Hawler Medical University , Erbil ,Iraq

email: bayansabr@ymail.com

Received: 2 February 2021

Revised: 24 February 2021

Accepted: 7 April 2021

Published: 25 October 2021

Diyala Medical Journal 2021:21(1): 28-34

\section{Abstract}

Background: The aim of the study was to know noise induces hearing loss and the effect of the noise on peshmerga that participated in the Daesh war in Erbil city. One of the health problems or most common forms of sensorineural is the noise induced-hearing loss. depending on the exposure noise induce cause damaging of the cochlea. So, one of the causes of noise induced hearing loss is exposure to the excessive noise.

Objective: To determine noise induce hearing loss among peshmerga participated in the Daesh war in Erbil city.

Patients and Methods: In the present study, a total of (253) Peshmerga of four special brigades who exposed to noise in the Daesh war in Erbil city was performed, also pure tone audiogram was done for each peshmerga in the Auditory department at Hawler teaching hospital. Also, pure tone audiogram and firearm noise levels for the right and left ear for each degree of hearing loss for the range of the noise induced hearing loss $(4000 \mathrm{~Hz})$ performed and hearing loss range in dB. Slight/Mild from 16-40dB, Moderate/Moderate severe from 41 70dB, and Severe/ Severe profound from 71-120 dB. were evaluated for each peshmerga in the auditory department at Hawler teaching hospital to know the cause of inducing hearing loss. Subjects answered a questionnaire and underwent threshold tonal audiometry.

Results: Two hundred and fifty-three peshmerga who participated in the Daesh war, was enrolled in this study that subdivided into four age groups (20-29), (30-39), (40-49), (50-59) years, pure tone audiogram was done for each peshmerga for right and left ear.

Conclusion: Because of the nature of the profession military, the common disease in the military is induce hearing loss is caused by noise. Hearing is the vital origin during exposure to loud noise. So, prevention is needed and to be a learner with care to the use of hearing protection device.

Keywords: Peshmerga, noise, audiogram, daesh 


\section{Introduction}

As a result, from exposure to elevated sound pressure levels, hearing abnormalities may occur, such as high-intensity noise. Acoustic trauma may occur due to following exposure to short-lasting impact noise and intense [1].

One -third of all individuals with hearing loss attributed to noise exposure.This is an estimation of the world Health Organization [2]. Depending on the activities in their career, military personal may be exposed to continuous and intermittent noise or to noise from a firearm [3].

One of the activities individuals exposed to high-intensity noise is handgun shooting, which is common in the military career [4].

When the middle ear is injured which when exposed to high-intensity noise, in this case causes sudden hearing loss, fullness, or the ossicular chain may be completely destructed. There is still a debate about the noise induce damage despite the prevalence of noise induced hearing loss [5].

As a result of the exposure to the auditory system, the noise induces hearing loss which is the deafness caused by the long term to exposure for a prolonged time if individuals remained in a noisy environment their hear will be impaired [6]. About $40 \%$ of people have noise induce hearing loss after the age of 75 years [7].

In the world, Noise induce hearing loss is the most prevalence occupational disease. [8]. Due to noise exposure in the workplace, noise induced hearing loss is a significant health problem $[9,10]$.

Hearing can recover after several days or hours because moderate noise exposure temporary can lead to a threshold shift [11].
Auditory sensitive exposure to noise variation is due to the functional status of outer hair cells [12]. Damage of presynaptic ribbons and postsynaptic amage nerves may be happened after noise exposure [13-15]. As a result of a single or repeated sudden noise exposure in the war which in general refers to acoustic trauma, hearing loss can occur [16].

After exposure to a higher level of noise cochlear damage over a short period of time [17]. $5.3 \%$ worldwide population is noise induced hearing loss, which is the most common form of sensory impairment and as a result of integral to the accurate and rapid processions speech information, hearing is critical to the performance of military personal [18].

Exposure to noise is responsible for near $10 \%$ of hearing loss in individual in veteran's military, especially soldiers who participated in the military. High intensity of various types of noise will be affected them at some point [19].

On the other hand, age is the most common form of impairment which related to hearing loss in older individual [20].At high frequency, hearing loss startss with a prevalence of $35 \%$ of people over 65 years of age [21-23].

\section{Patients and Methods}

A total of (253) Peshmerga of the special brigade that participated to four age groups, from (20-29,30-39,40-49,50-59 years) who exposed to impact noise in Daesh war in Erbil city was performed.

Also, pure tone audiogram and firearm noise levels for the right and left ear for each 
degree of hearing loss for the range of the noise induced hearing loss $(4000 \mathrm{~Hz})$ are performed and hearing loss range in $\mathrm{dB}$ for age groups from (20-29,30-39,40-49,50-59 years) are slight/mild from $16-40 \mathrm{~dB}$, the range of the noise induced hearing loss are $(17.2 \%, 35.4 \%, 36.2 \%, 36.1 \%)$.

For moderate/moderate severe from 41$70 \mathrm{~dB}$ are $(20.7 \%, 18.5 \%, 25.5 \%, 30.1 \%)$, and severe/ severe profound from 71-120 dB are $(5.2 \%, 3.3 \%, 12.8 \%, 10.8 \%)$ for the right ear. For the left ear, noise induced hearing for $4000 \mathrm{~Hz}$ were evaluated for each peshmerga in auditory department in Hawler teaching hospital range and degree are $(20.7 \%, 29.2 \%$, $29.8 \%, 30.1 \%), \quad(17.2 \%, 20.0 \%, 34 \%$, $30.1 \%), \quad(6.9 \%, 0.0 \%, \quad 6.4 \%, \quad 14.5 \%)$ respectively.Each subject answered the questionnaire, and examined his/her threshold tonal audiometry.

\section{Statistical analysis}

The data were performed using the Statistical Package for Social Science (SPSS) version (25).

\section{Results}

Due to the transfer function of the ear, $4000 \mathrm{~Hz}$ is the typical notch, the ear acts as a passive filter when any object facing a sound. At $4000 \mathrm{~Hz}$ NIHL is observed to decrease the sensitivity of hearing in the higher frequency that's why we examine the right and left ear at $4000 \mathrm{~Hz}$ (hearing frequency). Two handred and fifty-three peshmerga of special brigade was enrolled in this study that subdivided into four age groups (20-29), (30-39), (4049), (50-59) years, pure tone audiogram was done for each peshmerga for the right and left ear. Also, the percent for normal hearing and noise induced hearing loss for each two incidences of hearing loss (slight mild 16$40 \mathrm{~dB}$, moderate- moderate severe $41-70 \mathrm{~dB}$, severe/profound $71-120 \mathrm{~dB}$ ) for the right and left ear, was represented in Table(1).

In Table (2) valid, missing, mean, median, standard deviation and minimum value has been analyzed. For all age groups for $(250 \mathrm{~Hz}$, $500 \mathrm{~Hz}, 1000 \mathrm{~Hz}, 2000 \mathrm{~Hz}, 4000 \mathrm{~Hz}, 8000 \mathrm{~Hz}$ ).

Mean value are $(40.59,30.47$, 29.86,30.73,30.45,33.38,29.78) and median are $(40.00,25.00,25.00,25.00,25.00,30.00,25.0$ $0)$, and the standard deviation are (12.127, $20.455,20.410,22.622,24.535,26.732,27.872$ ) respectively. 
Noise Induce Hearing Loss among Peshmerga in Erbil City Participated in Daesh War

Table (1): Normal hearing loss and noise induce hearing loss frequently, percent

\begin{tabular}{|c|c|c|c|c|c|c|}
\hline & \multicolumn{5}{|c|}{ Age (year) } & \multirow[b]{2}{*}{ p-value } \\
\hline & $20-29$ & $30-39$ & $40-49$ & (50-59 & & \\
\hline Rt. Ear 4000 Hz Normal & $\begin{array}{c}33 \\
56.9 \% \\
\end{array}$ & $\begin{array}{c}28 \\
43.1 \% \\
\end{array}$ & $\begin{array}{c}12 \\
25.5 \% \\
\end{array}$ & $\begin{array}{c}19 \\
22.9 \% \\
\end{array}$ & $\begin{array}{c}92 \\
36.4 \% \\
\end{array}$ & \\
\hline Slight/Mild 16-40 dB & $\begin{array}{c}10 \\
17.2 \% \\
\end{array}$ & $\begin{array}{c}23 \\
35.4 \% \\
\end{array}$ & $\begin{array}{c}17 \\
36.2 \% \\
\end{array}$ & $\begin{array}{c}30 \\
36.1 \% \\
\end{array}$ & $\begin{array}{c}80 \\
31.6 \% \\
\end{array}$ & 0.003 \\
\hline $\begin{array}{l}\text { Moderate/moderate- } \\
\text { severe } 41-70 \mathrm{~dB}\end{array}$ & $\begin{array}{c}12 \\
20.7 \% \\
\end{array}$ & $\begin{array}{c}12 \\
18.5 \% \\
\end{array}$ & $\begin{array}{c}12 \\
25.5 \% \\
\end{array}$ & $\begin{array}{c}25 \\
30.1 \% \\
\end{array}$ & $\begin{array}{c}61 \\
24.1 \% \\
\end{array}$ & \\
\hline Severe/profound 71-120 & $\begin{array}{c}3 \\
5.2 \% \\
\end{array}$ & $\begin{array}{c}2 \\
3.1 \% \\
\end{array}$ & $\begin{array}{c}6 \\
12.8 \% \\
\end{array}$ & $\begin{array}{c}9 \\
10.8 \% \\
\end{array}$ & $\begin{array}{c}20 \\
7.9 \% \\
\end{array}$ & \\
\hline Lt.ear $4000 \mathrm{~Hz}$ Normal & $\begin{array}{c}32 \\
55.2 \% \\
\end{array}$ & $\begin{array}{c}33 \\
50.8 \% \\
\end{array}$ & $\begin{array}{c}14 \\
29.8 \%\end{array}$ & $\begin{array}{c}25 \\
30.1 \% \\
\end{array}$ & $\begin{array}{c}104 \\
41.1 \% \\
\end{array}$ & \\
\hline Slight/Mild 16-40dB & $\begin{array}{c}12 \\
20.7 \%\end{array}$ & $\begin{array}{c}19 \\
29.2 \%\end{array}$ & $\begin{array}{c}14 \\
29.8 \%\end{array}$ & $\begin{array}{c}21 \\
25.3 \%\end{array}$ & $\begin{array}{c}66 \\
26.1 \%\end{array}$ & 0.004 \\
\hline $\begin{array}{l}\text { Moderate/moderate severe } \\
41-70 \mathrm{~dB}\end{array}$ & $\begin{array}{c}10 \\
17.2 \% \\
\end{array}$ & $\begin{array}{c}13 \\
20.0 \%\end{array}$ & $\begin{array}{c}16 \\
34.0 \%\end{array}$ & $\begin{array}{c}25 \\
30.1 \%\end{array}$ & $\begin{array}{c}64 \\
25.3 \% \\
\end{array}$ & \\
\hline Severe/profound 71-120 & $\begin{array}{c}4 \\
6.9 \% \\
\end{array}$ & $\begin{array}{c}0 \\
0.0 \% \\
\end{array}$ & $\begin{array}{c}3 \\
6.4 \% \\
\end{array}$ & $\begin{array}{c}12 \\
14.5 \% \\
\end{array}$ & $\begin{array}{c}19 \\
7.5 \% \\
\end{array}$ & \\
\hline Total & $\begin{array}{c}58 \\
100 \% \\
\end{array}$ & $\begin{array}{c}65 \\
100 \% \\
\end{array}$ & $\begin{array}{c}47 \\
100 \% \\
\end{array}$ & $\begin{array}{c}83 \\
100 \% \\
\end{array}$ & $\begin{array}{c}253 \\
100 \% \\
\end{array}$ & \\
\hline
\end{tabular}

* p-value represents the significant difference between the right and left ear

Table (2): Valid, missing, mean median, standard deviation deviation and minimum value

\begin{tabular}{|l||l||c||c||c||c||c||c||c||}
\hline & & $\begin{array}{c}\text { Age } \\
\text { Years }\end{array}$ & $\begin{array}{c}\text { Rt_250 } \\
\text { Hz }\end{array}$ & $\begin{array}{c}\text { Rt_500 } \\
\text { Hz }\end{array}$ & $\begin{array}{c}\text { Rt_1000 } \\
\text { Hz }\end{array}$ & $\begin{array}{c}\text { Rt_2000 } \\
\text { Hz }\end{array}$ & $\begin{array}{c}\text { Rt_4000 } \\
\text { Hz }\end{array}$ & $\begin{array}{c}\text { Rt_8000H } \\
\text { z }\end{array}$ \\
\hline \hline $\mathrm{N}$ & Valid & 253 & 253 & 253 & 253 & 253 & 253 & 253 \\
\hline \hline & Missing & 0 & 0 & 0 & 0 & 0 & 0 & 0 \\
\hline \hline Mean & & 40.59 & 30.47 & 29.86 & 30.73 & 30.45 & 33.38 & 29.78 \\
\hline \hline $\begin{array}{l}\text { Std. } \\
\text { Deviation }\end{array}$ & & 40.00 & 25.00 & 25.00 & 25.00 & 25.00 & 30.00 & 25.00 \\
\hline \hline Minimum & & 12.127 & 20.455 & 20.410 & 22.622 & 24.535 & 26.732 & 27.872 \\
\hline \hline Maximum & & 20 & 0 & 5 & 0 & -5 & -10 & -10 \\
\hline
\end{tabular}

\section{Discussion}

When examining the right ear at $4000 \mathrm{~Hz}$ (hearing frequency), Table (1) shows that only $36.4 \%$ of the participants were of normal hearing and $63.6 \%$ are noise induced hearing loss. The incidence of moderate/moderate-severe hearing loss (HL) was $24.1 \%$ in the whole sample, and the incidence of severe/profound HL was $7.9 \%$. A significant $(\mathrm{p}=0.003)$ association was detected between age and the severity of hearing loss, where it is evident in the table that high rates of moderate and severe hearing loss are associated with ages of 40 years and above. The incidence of severeprofound hearing losswas $12.8 \%$ among those aged 40-49 years, and it was $10.8 \%$ among those aged 50-59 years. These rates are higher than the rates $(5.2 \%$ and $3.1 \%)$ among those aged 20-29 and 30-39 respectively. Nearly the same pattern can be 
observed for the left ear where it is evident in the table that the incidence of moderatesevere HL was higher among the older ages compared with the younger ages $(\mathrm{p}=0.004)$.

As we note the incidence of moderate/moderate-severe hearing loss (HL) was $24.1 \%$ in the whole sample that's agreed with record of Union army solders document that 33\% had diagnosed hearing loss. (Swell, et al. 2004).

In the present study found that was moderate hearing loss about $23.7 \%$ and severe hearing loss is \% 7.9 and this is disagreed with the study by (Naila Azam,2010), and there was moderate hearing loss about $47.1 \%$ of the case with hearing defect and severe hearing loss is $30.0 \%$.

In the Swedish study (Sergio GonzalezGonzalez,2017) say that $17 \%$ reported experiencing hearing loss [18]. The rate ranged from $11 \%$ at 30 years age, and $24 \%$ among those over the age of 50. So the prevalence was $26 \%$ among those who had been exposed to heavy weapons fire, that agreed with our study that the rate ranged from $10.8 \%$ at 30 years of age and disagreed with the range of $3.1 \%$ among those over 50 years old.

Also, in our study as we see noise induce hearing loss has significantly higher among peshmarga in the Daesh war for all age groups in Erbil city which is of63.6\%, and this result agreed with according study by Timothy et al (2015) that combat experience was associated with a $63 \%$ increased risk for hearing loss.

Also, our result is in line with the study done by Jennifer Fink (2014) .In the Gulf War that $60 \%$ of deployment are noise induce hearing loss. As we note in Table (1), noise induce hearing loss for the degree slight/ mild, moderate /moderate severe, severe. There was significant differences between age groups for right and left ear respectively, (p- values are 0.003, and 0.004).

\section{Conclusions}

Because of the nature of the profession military, the common disease in the military is induced hearing loss by noise. Hearing is the vital origin during exposure to loud noise. So prevention is needed and to be learner with care to the use of hearing protection device.

\section{Recommendations}

Noise induced hearing loss as a hearing impairment rises due to mostly exposure to excessive or loud noise and their hearing been affected, for health education, for example there are many methods to the use of hearing protection, so address barrier is needed.

\section{Source of funding: Nill.}

Ethical clearance: First, I would like to thank and express my deep gratitude to the group of auditory departments, many thanks to Dr. Bawaji who was always help me.

\section{Conflict of interest: Nill}

\section{References}

[1]Humes L, Bess F, fundaments elm audiologic, Art med. Porto Alegre, 4th edition. Amazon (2008).

[2]Nudelman AA. PAIR, revinter, Rio de Janeiro. Brazil, (2001).

[3]Ylikoski M. Prolonged exposure to fun fire noise among professional soldiers. Scand JWork Eniron Health,20(2):1994, pp.87-92. [4]Noise and Hearing loss. In: National Institutes of Health. Consensus Development 
Conference Statements. Edited by; Services USDoHH. Dethesda, MB:1990.

[5]Masterson EA, Tak S, Thiemann CL. Prevalence of hearing loss in the United States by industry. Am J I Nd Med. 2013,56:670-81.

[6]Tonghui Ding, Aihui Yan, Ke Liu.Whats noise induce hearing loss. British Journal of Hospital. (2019) 80, No.9. doi.org/10.12968/hmed.2019.80.9.525.

[7]Eileen Daniel DEd. Noise and hearing Loss: A Review. Sh J.2007, Volume 77, Issue 5. Doi. Org/ 10.1111/j. 1746-15-51. [8]Kou- Hong Chemosis- Bin Su and KowTong Chen.An overview of occupational noise-induce hearing loss among workers: epidemiology, pathogenesis, and preventive measures,2020, (65) 628.

[9]Nelson DI, Nelson RY, Concha-Barrientos M, Fingerhut M. The global burden occupational noise induces hearing loss. AM. J Ind. Med. 2005; 48:446-57.

[10]Sliwinska-Kowalska M, Zaborowski K. WHO environmental noise uidlines for the European region: a systematic review on environmental noise and permanent hearing loss and tinnitus. Int. J. Environ. Res. Public Health. 2017;14(10):1139.

[11] Lijuan Shi. Cochlear Cenesthopathy and Noise induce hidden Hearing loss. 2016, doi.org/ 10.1155/2016/6143164.

[12]R. Szalai. Nonlinear models of development, amplification and compression in the mammalian cochlea. Philosophical transaction of the royal society of London.2011; vol.369, no,1954, pp.41834204.

[13]S.G. Kujawa and M.C. Liiberman, adding to insult to injury: cochlear nerve degeneration after temporary noise induce hearing loss "The journal of neuroscience,2009. vol.29, no. 45, pp. 1407714085.

[14]L. Shi, L. Liu, T. He. ribbon synapse plasticity in the cochlea of guinea pigs after noise induce silent damage,2013; vol.8, no.12, Article ID e 1566.

[15]L.Liu, H. Wang, L. Shi. Silent damage of noise $\mathrm{i}$ on cochlea afferent innervation in guinea pigs and the impact on temporal processing.2012; vo.7, no.11, Article ID e 49550.

[16]Survorov G, Denisov E, Antipain V, ET AL. Effects of peak levels and number of impulses to hearing among forge hammering workers. Apple Occupy Environ Hay. 2002; 16:816-22.

[17]Shi L, Chang Y, Li X. Cochlear Cenesthopathy and noise hidden induce hearing loss. Neural plats. 2016; 2016:58490.

[18]Sergio Gonzalez- Gonzalez. Noise induce Hearing loss and tinnitus in military personnel. Mathews $\mathrm{J}$ of Emergency Medicine. 2017;2(2):027

[19]Gordon JS, Griest SE, Teilman EJ, Carlson KF. Audiologic characteristics in a sample of recently separated military Veterans: The noise Outcomes in Servicemembers Epidemiology Study (noise study). Hear Res. Pil:2016; 503785955(16):30290-30298.

[20]Someya S and Prolla TA. Mitochondrial oxidative damage and apoptosis in age related hearing loss. Mech ageing dev. 2010;131(7-8): 480-486.

[21]Yamasoba T, Lin FR, Someya S, Kashio A. Current concept in age - related hearing loss: epidemiology and mechanistic pathways. Hear. Res.203; 303:30-38. [22] 
Ynkaskas K. Prelude: noise induce tinnitus and hearing loss in the military. Hear Res. 2013; 295:3-8.

[23]Pfannenstile TJ. Noise induce hearing loss: a military perspective. Cur Open Otolaryngology Head Neche surg. 2014;22(5):384-387. 